\title{
Social Imagination and Solidarity in Precarious Times: The Case of Lower Class People in Post-Soviet Russia
}

\author{
Karine Clément \\ Associate Professor of Sociology, Director of the Andrew Gagarin Center for Civil Society and Human Rights, \\ Faculty of Liberal Arts and Sciences, Saint Petersburg State University \\ Address: Universitetskaya nab., 13B, Saint Petersburg, Russian Federation 199034 \\ E-mail: carine_clement@hotmail.com
}

\begin{abstract}
The paper seeks to enrich existing literature on group making by studying the process of group formation among lower class people in post-soviet Russia, which provides important findings on the way precarization and atomization in global neoliberal capitalism can be overcome. Drawing on a large database consisting of in-depth interviews in different regions and a few observations, the study sheds light on the way social ties and social imagination can develop among lower class people, who have been subjected to harsh social and economic destabilization. First, a process of inhabiting one's social and material environment has to enfold, along with the recovering of habitus or a sense of occupying a "normal" place in society, and regular interactions with people recognized as occupying a similar place. Second, rootedness in one's everyday experience gives lower class people the capacity to grasp the broader social space and to draw some lines of differentiation and division, while populist and anti-populist discourses can provide the background for acknowledging and naming new social divisions. To grasp these processes, the author argues, a comeback to such classics of critical (or structural-constructivist) sociology, as Marx and Bourdieu, would be useful.
\end{abstract}

Keywords: social imagination, habiting, everyday experience, lower classes, social cleavages, post-Soviet Russia, precariousness

Theories of globalization and post-modernism (Giddens, 1991; Beck, 1992; Melucci, 1989; Bauman, 2000), as well as theories of neoliberalism and precarization (Boltanski, Chiapello, 1999; Sennet, 1998; Standing, 2011) describe the end of the society, national society first of all, and the nomadification or atomization of individuals, their increasing mobility, destabilization and insecurization. Rootlessness gives rise to mourning the loss of social attachments and to new demands for social belonging, which are depicted in the literature as identity politics (for a critical view on the concept, Bauman, 2001; Brubaker, Cooper, 2000). However, identity politics or the search for identity seems to be an unsatisfactory concept for embracing the multiple forms of constructing social links and a sense of belonging. First, it appears to be too normative, assuming that they are "good" identity claims for the recognition of ethnic or sexual minorities or gender differences, ignoring the "bad" identity claims of the majority or the old-fashioned claim for the rec-

\footnotetext{
(C) Karine Clément, 2017

(C) Centre for Fundamental Sociology, 2017
}

DOI: $10.17323 / 1728-192 \mathrm{X}-2017-4-53-71$ 
ognition of the poor and exploited. Second, identity politics is too narrow a concept to embrace all the multiple social groups or social bonds being made. Still, the quest for social belonging and the suffering linked to individual isolation and insecurization are strong in our times, leading to the rise of populist or nationalistic politics or movements.

No doubt, this trend is developing all around the world. However, it seems that Russia is a valuable vantage point from which to look at it, since it is hard to think of another society that has so deeply been shaken and broken up. Indeed, Russia has experienced many twists and turns in a relatively short period, particularly since the collapse of the communist regime and the breakdown of the Soviet Union. At different times in the course of their lives, Russian people have experienced multiple crises and upheavals: the collapse of one great country (the Soviet Union) and the emergence of another (Russia), the substitution of communist ideology with free-market democratic ideology, brutal ups and downs of material and social status, the reversal of the bad and the good, several economic collapses, wars and the beginnings of civil wars. The radical and profound transformations that Russian society has endured since the end of the 1980s made it difficult for most people to maintain their ordinary and familiar (routine) relations to the world. In this sense, we can speak of a "cultural trauma" which shattered identity, atomized society, disoriented people and debased a wider sense of public meaning (Alexander et al., 2004; Sztompka, 2000). The result, at least in the most destabilizing period (the 1990s), was an atomized, scattered, and exploded society where people shared hardly any patterns of socialization. Almost every person had to make their own synthesis of the contradictory layers of life experiences; this rendered it difficult to figure out the society one lived in, and hindered the building of solidarities and common visions.

One of the consequences of the turmoil for the theoretical knowledge of our contemporary societies is that which is considered as commonplace in western sociology, the intuitive and non-reflexive sense of one's place or social location (Goffman [1974] refers to it as "frame" or "footing" in interactional contexts; Bourdieu [1990] talks about "habitus") appears to be problematic. Moreover, the shattering of "habitus" or the intuitive sense of the world and one's place in the world weakens people instead of emancipating them from oppressive social structures and the unequal distribution of capital.

Russia is obviously not unique in this situation. Many other countries have been subjected to upheavals, wars and other human tragedies. Moreover, at least one process breaking social ties is now global: social, labor and material precarization. This is a massive worldwide trend in neoliberal capitalism, abundantly analysed in the literature (Boltanski, Chiapello, 1999; Breman, van der Linden, 2014; Sennet, 1998; Standing, 2011). Precarization was all-pervading in the 1990 s in Russia, but continues to destabilize people and break solidarities, although it is not acknowledged as a political or social problem.

From this perspective, Russia provides a perfect example of an atomized society where most people are entrenched in their close and intimate environment of one's home and family, disengaging from the hostile and incomprehensible outer world. However, despite the weight of the atomizing dynamics, there are also countertendencies, particularly since the 2ooos, towards the building of social links and the recovery of a sense of 
social belonging, which is not limited to identity claims. The object of this paper is to look at such countertendencies through the analysis of selected cases of communalization or connectedness in the everyday life experience of lower class people.

Lower class people are the subject of the paper for two main reasons. One is that they represent the majority of the Russian population: those people who live with incomes below the official (undervalued) poverty line or not much higher, or who live under the threat of falling into poverty if they lose their job, fall ill or have growing children. To give only one estimation, according to a recent poll (May 2017), around $40 \%$ of the population try to save money on food and clothes ${ }^{1}$. A key feature of Russian poverty is that it is not limited to specific groups (although the disabled, families with many children, single-parent families and retirees are among the most vulnerable categories), but make up a large part of low-paid workers, non-qualified and qualified. From this perspective, lower class people in Russia fit into the growing category of "working poor", which is one of the features of precariousness all around the world. The second reason to concentrate on lower class people is that this category of people is emblematic of the new precarious and uncertain times of post-soviet capitalism, if speaking of Russia and other post-soviet states, or neoliberal global capitalism, if speaking of world trends. They do not form a class in the sense of homogeneous and self-conscious group (a reason for which the more conceptual term of "working class" has not been chosen as the primary term, although they empirically almost merge), but they represent a wide category of people facing similar material and social insecurity.

Except for a few exceptions mentioned in the text, data on lower class life experience come from a large database collected in 2016-2017 within a research project devoted to everyday nationalism ${ }^{2}$, which consists of twelve observations of everyday interactions and 220 in-depth interviews on their everyday life experience with people from six regions with different social and professional profiles. Most of the people interviewed are former or actual blue-collar workers or low-wage workers (many retirees are also still working in order to survive). The cases explored in this paper illustrate the ways some people from the bottom, who were harshly destabilized and disoriented by the neo-liberal reforms and turmoil of the nineties, or whose parents were, arrange new spaces for living a more or less good life, which implies developing attachments to certain things and people.

1. https://wciom.ru/index.php?id=236\&uid=116154.

2. Ongoing research on "Patriotism in Contemporary Russia" under the project "Living Together: Issues of Diversity and Unity in Modern Russia: The Historical Legacy, the Modern State, and Society" (2016-2017). Research supported by the grant for the Foundation for Support of Liberal Education at the Center for Historical Research at the National Research University Higher School of Economics Saint Petersburg and Gagarin Center for Civil Society and Human Rights. 


\section{The Main Thesis: From Desubjectivation to the Recovery of Social Consciousness}

Precariousness was maybe nowhere so widespread and all-pervading as it was in the 199 os in Russia. Blue-collar workers or industrial bottom-workers, who were the absolute majority of the soviet population, were among the first victims of precarization, because of deindustrialization, the loss of their symbolic significance as the mythicized Soviet proletariat and the weak mobilizing potential of their organizations. The field studies I conducted in the 199os among industrial workers led me to describe their life's precarization as a process of desubjectivation (the tendency towards the loss of some sense of the self and agency, see Clément, 1999). In the 1990s, they lost two thirds of their average real wage, most of their social wage and protections, including guaranteed employment, as well as their social image of the leading class of Soviet society. However, workers have stood by relatively passively in the face of such hardship, since they had lost themselves in the turmoil of the market reforms. Most of them lost points of reference and orientations, experiencing trouble identifying themselves and identifying the society in which they live. Many talked about themselves in derogatory terms: "a small screw in the soulless machine", "nothing", "unneeded people", "cattle" or "slaves". The high degree of worker alienation and atomization was noticed by other scholars having done research at that time (Ashwin, 1998).

Industrial workers were not the only ones to be shaken by processes of desubjectivation and precarization, although the experience of declassification was certainly more painful for them. Which is why it is all the more striking to discover now, after more than 25 years of reforms, that many people, including blue-collar workers, display a social consciousness that was lacking in the 1990s. In this paper, I give some empirical evidence of the new sense of the social that I noticed during the most recent research (2016-2017) and point out the processes leading to the renewal of social consciousness.

First, what do I call social consciousness? This is the sense of one's own and others' positions in the social space and a certain representation of society. This is not only the mess, the collection of lost atoms or a black box, like it was for a long time for many of the people I interviewed in the 1990 s and 2000s. In the eyes of many lower class people interviewed over the past few years, society presents some obvious lines of cleavages: between the poor and the rich, between the "productive" or "manual" workers, on the one side, and the "paper" workers, employers, civil servants, bureaucrats or corrupt politicians, one the other side. A cleavage also appears separating people in the regions from people in the big central cities.

This paper addresses group-making in a time-space of high turbulence (post-soviet Russia). The process of group-making is a traditional sociological issue and the literature devoted to its study is too large to be fully discussed. What this paper proposes is to discuss some specificities of group-making in a society destabilized in the 1990s by the loss of a big part of its territory, by the dissolution of its national identity, by harsh economic 
reforms and the symbolic destruction of the traditional soviet class-structuration of the society.

By analysing and comparing interviews between people who witness a sense of social belonging and those who do not, it is possible to identify two interconnected processes contributing to the recovery of social consciousness: the process of habiting one's life or surroundings; and the process of opening to the imagined communities of ours and theirs.

\section{Inhabiting}

At [the factory], there is a room where people can relax at lunch time. And we really like to spend time there and talk together. Doesn't matter, about what, it can be about wives, prices, or politics. The important thing is that we feel comfortable and free to speak there. It's really pleasant, I learn a lot in this way. It's far more interesting and more convincing, than what we have on TV.

(Operator, 40 years, Saint Petersburg)

This quote is representative of workers' search for opportunities to talk together among themselves, workers who share the same life experience, especially the same labor experience. In such settings, the workers feel free to talk about everything that matters for them without being shy or feeling constrained by rules of correct behavior or speech. The enthusiasm and strong need for free and equal communication inside the workplace can be illustrated by a collective discussion triggered by the sociologist's presence in a water treatment plant in the industrial monotown of Rubtsovsk in June $2011^{3}$. I wanted to learn more about the state of affairs in the monotown, and the blue-collar workers - male, 30-40 years' old - began to discuss the issue of a town in decay, abandoned by the political authorities, where only the blue-collar workers tried to do something to save the infrastructure and make life liveable for the town's citizens. They used the presence of the sociologist to talk to each other rather than to answer the questions, which were forgotten in the course of their talking together. In the same town a few years later, in July 2017 , while I was conducting fieldwork on everyday patriotism, working people made multiple allusions to the fact that they had already (or "just today") discussed the point with their colleagues at work. In many other places around Russia where I have interviewed people over the last few years, working people report on typical conversations with their colleagues on very different issues, beginning with private and personal things (the children's education and leisure, their wives/husbands, etc.), but including also - which is new compared to interviews and echoes from the 1990 s and 2000 - political issues. Moreover, workers speak of these conversations on political issues as something "normal" and "obvious". "Of course, we talk about it at work". Maybe women are less prompt to talk politics (some say that these are male issues), but it is not the case of all women.

3. Fieldwork on urban movements in 3 towns (2011-2012), see Clément, 2013. 
Such spaces for informal conversation have always existed in soviet and post-soviet enterprises, but, contrary to the 1990s, the quest for one's own space of comradeship is now going beyond the enterprise's walls. The flat itself, which was closed to strangers not belonging to a narrow circle of relatives during the harsh time of the 1990s, is now being opened to welcome workmates and friends or acquaintances from other workplaces. This has partly to do with the fact that more workers have been able to renovate their flats, which are now more "presentable" and, thus, hospitable. More generally, workers who I have met frequently depict their time outside the workplace as being full of social and informal activities in the course of which they can develop friendly or cooperative relationships with their co-workers or workers from other places. These are, for instance, fishing, walking in the countryside, playing sport, doing some manual work together (fixing cars, building dachas, etc.), looking after children. Compared to the 1990s, where most of the time outside the workplace was devoted to working (informally, domestically, etc.) for money or to survival practices involving workers individually, often putting them in competition with each other, time off is now more dedicated to relaxation, leisure and informal communication.

For instance, some workmates from Ford in Vsevolozhsk (Leningrad region) regularly meet for volleyball. Others in Astrakhan regularly meet for fishing on the Volga River. Many find their space of relaxation in garages where they work on or fix equipment, often in small groups of peers. Of course, they often drink together in these occasions. If these activities are rather male-dominated, activities at home and traditional tea-parties are the domain of women. Once again, these activities are rather pursued for their own sake (not for survival) and for sociality.

Women especially, but men also, often use outdoor spaces for chatting, looking after the neighborhood, or having good time singing or playing. This is especially the case when the courtyard ( $d v o r)$ between several apartment buildings is looked after by the inhabitants themselves. I have seen many such places since the implementation of the new housing legislation (2005), which gives the inhabitants the right to self-organize to manage their own buildings. Such soviet practices as subbotnik (volunteer workday) have reappeared with new meanings, especially for cleaning the courtyard, gardening or painting. These occasions for socializing are appreciated by most of the residents. As an old woman in Astrakhan exclaimed after such a subbotnik (May 2008 ${ }^{4}$ ), "It was the first time in a long time that I saw so many people in the courtyard. It was as if I had woken up after a 20-year-long hibernation!" I have seen dozens of beautiful and welcoming courtyards, arranged with flowers, paintings, wooden sculptures by handymen in all the towns I have visited since the end of the 2ooos. In Perm, neighbors of a completely restored block of flats in an old industrial district arranged the basement for a common recreation and celebration space. In Pushkin (St. Petersburg), neighbors put a long table, arranged flowers and installed a fountain in their courtyard. They regularly organize common celebrations, sharing food and drinks, inviting all the neighbors, and their relatives and friends.

4. Fieldwork on housing self-management (2007-2011), see Clément, 2015. 
They even celebrate the most popular holiday in Russia, New Year, meeting together in the courtyard at midnight, and dancing and drinking until late in the night.

The lower classes also invest in public places, sometimes using official celebrations for their own use and at their own convenience, without any piety towards the official dramaturgy. For instance, in Perm at the 2016 Victory Day celebration on May 9, many bluecollar workers living in one neighborhood came to the "The Immortal Workshop" public event, which commemorates Perm industrial workers, who produced armaments during WWII. The event was celebrated in the industrial district Motovilikha and accompanied "The Immortal Regiment" march, which took place in the city center. People gathered to commemorate and honor the veterans of WWII and to socialize. They formed small groups and circulated, hugging each other, joking, recalling stories from the great times of the industrial district, mocking the official authorities and toasting. Many were secretly drinking (the public consumption of alcohol was banned that day), which added to the relaxed and joyful atmosphere of the gathering.

This is not to say that nothing like this existed before, during soviet times or just after the fall of the USSR. I instead argue that these places and activities of sociality are becoming more widespread; more people, especially from the lower classes, are engaging in them. More importantly, they engage in these activities with their own meanings, which differ in each situation or interaction, but have in common a sense of being able to speak freely and among "themselves", people sharing the same positions, on an equal footing, without ceremony and in sometimes crude and irreverent language. On these occasions, people rarely complain (or they do it ironically, distancing themselves from the role of victims), rather they mock the adversity and hypocrisy of the better off. They talk about everyday life with many concrete and colorful details, using irony and allusions to the tacit knowledge of commonplaces shared by all the interlocutors. They praise themselves for "making a go of it" or "doing it by ourselves".

What happened in the meantime? How can we explain this new trend? I would argue that since the end of the 1990s, the growing economic and political stability, especially the sense of stabilization, give people, particularly from the lower classes, some ground under their feet on which they could build some other ways to understand the world and their place in it. Stability sometimes means an improvement in wages and labor conditions, or at least the end of wage arrears, and a production revival. It means the stable payment of pensions. It means stable government since 2000 and the restoration of the state. All this, at least in the 2000 s and until the global economic downturn of 2008 , allowed most people to recover from shock, positional suffering (Bourdieu, 1999) and selfdepreciation, and provided them with a sense of normality and ordinariness.

Many lower class people describe their everyday life as having always been marked by poverty or need. However, they interpret it as "normal" or "ordinary". "It has always been like this, nothing new. We just keep going. No problems, no crisis, just the usual things" (female, June 2016), said an ex-worker pensioner who works now as a concierge in St. Petersburg and lives in very poor housing conditions. Contrary to the "litanies and laments" heard by Nancy Ries (1997) in the 1990s, lower class people in the 2010s rarely complain 
about their lot. They can blame somebody, ironically criticize some aspects of their life experience, talk to others about it with enjoyment, but they rarely cry about it. The same concierge explained in detail how she loves her little decaying one-room apartment, how she feels comfortable there and "at home"; she describes the little gifts she regularly makes to her relatives, the help others give her; and values her part-time job as a concierge (which she was "very lucky" to find) highly. Although it may look like resilience or the process of never-ending individual adaptation to hardships, it is rather a striving to get some satisfaction or enjoyment from life. Striving to make one's life habitable and even comfortable instead of binding oneself to the neo-liberal demands of individual "adaptation" or devaluating one's life in regard to its failed character from the point of view of the new market ideology. For example, this same concierge gets pleasure in talking with people who share the same life experience, talks about her friends and relatives as living in even worse conditions than she lives in, finds a way to buy some good coffee and sweets and take some to her friends for a moment of chatting. In a word, she feels "good" in life, at work as well as at home.

A great change seems to have unfolded in the way people, and particularly people from the lower classes, relate to their life and environment. From the desubjectivation and the disorientation of the 1990s, many today fully inhabit their world and have repositioned themselves in their surroundings. To use Bourdieu's concept of habitus, the process has been from a "broken habitus" (Wacquant, 2002: 1499) or "split habitus" (Bourdieu, 2004: 94-114) (the old positions and dispositions incorporated through the experience of soviet social structures having come into contradiction with the new postsoviet social disorder, which led to the failure of people's practices and common sense) towards a recovered habitus that again fits the social structures and allows the social agent to act in the best way intuitively. This intuitive and comfortable (which implies being "at ease" with the surroundings and one's position) sense of one's position provides the ground for people to seek for connectedness and sociality. As Crossley reminds us, "the habitus forms the practical-social basis for innovative and improvised action. It consists of forms of competence, skill, and multi-track dispositions" (Crossley, 20o1: 8). This is why habitus allows people, especially those who have been weakened and symbolically put down after the fall of the communist regime, particularly the working class, to take steps in their environment, which had long been experienced as hostile, unfamiliar (everything had changed), insecure and incomprehensible. This stepping towards the social world, through encounters, interactions and actions, fuels the mechanisms of rebuilding a coherent habitus. Connectedness and interactions (especially with people sharing the same social position) are indispensable for the rebuilding of habitus, schemata of visions and divisions. Habitus is first forged through joint activities and interactions with significant others, "people like us" (Wacquant, 2014: 126).

For the working class, especially, a rebuilt habitus (which is practically coherent with social structures) requires the reconciliation of the person with materiality and bodyness, while an abstract or reflexive striving for meaning, which could be essential for educated upper or middle classes, is not enough. This is why inhabiting as well as embeddedness 
in one's environment, rootedness in one's material and corporal life is so important (on the importance of the body, see Wacquant, 2014). The significance of bodyness or the reconciliation with one's body, the perception and sense of the world through the body, is illustrated by the value many current or ex-blue-collar workers give to the practice of doing something with their own hands, to getting enough to eat and drink, to arranging one's own place to live and to welcoming guests. It can also be illustrated by the importance of sport for men especially, of beauty care for women and of gender roles for both.

More than bodyness, I would stress the importance of the down-to-earth or very pragmatic anchorage in (or the sensitive experience of) one's daily life as a necessary starting point for lower class people to rebuild the sense of their place in the social world. It supposes the re-foundation of the mundane and the inhabitation of the surrounding and material environment, that is feeling the deep physical, emotional, sensitive, mindful, and moral relationship to places, people, and things that are a regular part of one's daily life. It is the essential condition for engaging with and making sense of the world and one's life experience. The concept of inhabitation or habitability is important here, what Morris (2016: 8), studying working class people in a Russian monotown, calls "the striving for mundane comfort and ordinariness". Inhabiting means living one's life despite insecurity and uncertainty, finding it normal, ordinary, even "good". Inhabiting is "making habitable the inhospitable and insecure space of lived experience" (Morris, 2016: 236). By these efforts and practices, people turn from the "suffering of positions" (Bourdieu, 1999) to "enjoying one's place". The recovery of habitus and a sense of one's place does not mean that lower class people would gain an awareness of any domination or social inequality, but they gain the ability to look at the social world without feeling lost in chaos.

As a whole, the process of inhabiting leads to re-connectedness, to the building of social ties and to group making. People arrange their own comfortable place to live in, which means regular interactions with significant others, that is, with people sharing a similar life experience. Despite globalization and the progress of virtual communication, physical co-presence and face-to-face interactions or interaction rituals (Durkheim, 1912; Collins, 2004) are still key, especially concerning working class people, who value embodied activities and communication, for the formation of solidary groups. It is apparent in my current fieldwork that most of the (ex-)blue-collar workers interviewed for the research project on nationalism prioritize the company of their peers for leisure or shared activities (once again, in complete opposition to what was the workers' motto of the 1990s: "Each one for oneself"). For most of them, the blue-collar milieu, or the "simple", "ordinary" workers, are the referent group, the group of belonging and of valuation.

\section{Imagine the Community of Enlarged "Ours"}

A second striking feature, which shows up in my recent fieldwork concerning lower class people, is the development of their social imaginary, that is their opening to imagined communities of enlarged ours and theirs. This finding is in complete opposition with the expressed inability to figure out Russian society in any way except for aesthetic emotional 
pictures (a tunnel, a ravine, a mess) - the dominant pictures I collected in interviews until recently. More and more frequently, cleavages, which are based on social criteria, are expressed, in interviews or informal conversations. Social cleavages are mentioned spontaneously, seeming congruent or salient in everyday life. The most frequently named cleavages are between the rich and the working (wage) people, between blue-collar workers and the employers or office workers, between the provincial towns and the big cities. A very clear cleavage separates those who work in earnest for the good of the country, who do something useful or productive (or have done, if speaking of pensioners) and those who only talk or live at the expense of the genuine workers. It is something quite new, since the workers (especially industrial ones) were long denied any social recognition, their work being depicted as outdated and unneeded in the new liberal economic order; their competences and know-how were dispraised. It is also worth stressing that new cleavages are arising which are not the traditional dividing line between "the people" and "the power", which has been dominant for a long time, supported by the discourse of the ruling elite and the liberal opposition. The new cleavages reveal a growing sense of social inequality and unfairness, which is strongly expressed by blue-collar workers, people working in the production sector, pensioners and the lower and middle classes from the regions. They indicate the formation of a sense of social belonging that dissolved after the breakdown of the soviet system. Workers use frequently the pronoun "we" to refer to collective social entities, which are something wider than the mere small family circle or other restricted circles of "ours" (traditional Russian term svoi refers to people whom I personally know and with whom I interact on the basis of mutual aid and interdependence). In many interviews and conversations, the "we" refer to general categories, such as "the hard-working people", "the ordinary folk", "ordinary citizens" and even "the working class", which had long disappeared from public discourse and from everyday conversations after the fall of the USSR. What is awakening here is the social imagination, the ability to imagine other people having some common experience and understanding of life.

I first provide some empirical evidence to underlie the point, and then turn to some theoretical elaborations on the on-going group-making processes.

Astrakhan, June 2016. From an interview with a blue-collar worker repairing the roof of an apartment building: "Nothing will never change in Russia in our lives. What can change? Everything has been seized, it's business, it is profitable for them, do you understand, it's profitable to take everything from the workers, to pay them so little. . . . They talk a lot, but talking is easy, they promise a lot, but nothing changes."

Astrakhan, June 2016, collective interview in a courtyard with some members of the housing committees and some less active residents (all women, 30-60, lower class). "(Putin) lifts the country up? Not our country, maybe Syria or Crimea."

"You know, I don't think he lifts our country up, nor Crimea and Syria."

"Yes, he lifts up the well-offs."

"All the money is offshore. .. . Nothing remains in Russia." 
"Yes, he works for the rich."

"Banks also do well, our welfare funds go to the banks."

"What did Putin do for the pensioners? What? Nothing! No-thing! Only empty words."

"They live very well, and we struggle to survive."

Perm, May 2016, an informal conversation with two blue-collar workers. The same two workers mentioned above that were standing in the central place of the industrial district Motovilikha, celebrating the Victory Day, expressed a keen sense of social inequality and social belonging. They referred to "we" as "simple working people". The "simple working people" with whom they identified included those who work for a low salary and cope with very concrete difficulties in life (e.g., food prices, cost of utilities, low wages, the condition of roads and buildings). The alternative category of "them" included the "oligarchs," property owners or powerholders, as well as people from Moscow and Saint Petersburg (who "get salaries in dollars, shop in dollars, and think in dollars," as one of the workers put it). "They" are rich, greedy, line their pockets, and live in a world completely disconnected from the world of simple people; "they" symbolically dominate (they are "up there," "on top"). The two workers' narratives constantly moved back and forth between these two categories of "top" and "bottom."

For instance, they pointed out the contradiction between the richness of Russia's natural resources and the poverty of its inhabitants, particularly among those working in the gas sector:

Oleg: "Why do we sell gas to everybody but don't have gas for our houses?"

Anton: "We sit on oil."

Oleg: "I work for Gazprom and have no gas in my own house."

They attacked the hypocrisy of official statistics (here on average salary) and stood up for more equal salaries.

Oleg: "For example, if the governor receives half a million, and the nurse in a kindergarten has 7,000, the average could be 29,000 (rubles a month). I think that the average salary should be counted with reference to the workers. Or to equalize all the wages. The governors' wage, mayors', ... heads of administrations, Putin's ... To equalize with that of a nurse. Let them work as a nurse for a while! To wipe kids' asses for 7,000 !"

Oleg and Anton were talking loudly, often looking at other people standing nearby, addressing their words to them also, and being confident of their approval and comprehension, as if they were certain the others shared the same tacit knowledge and life experience. Moreover, it seemed to me that the audience of the message was not limited to the public physically standing nearby, but was wider, an imagined public of people knowing from their everyday life what does it mean to have no gas at home and to earn 7,00o rubles for wiping kid's asses.

Moscow, metro driver, February 2017: "When you [referring not so much to himself as to other poor-working people] see that so many people earn so little money from their own work, it arouses a feeling of hatred".

A high-skilled young blue-collar worker, St. Petersburg, Jan. 2017: “I love my job, I really enjoy it. And I want to earn money from it. However, it turns to be without any value. Human labor is not valuated anymore.... Those fat arseholes, sorry, who 
sit in their chairs in the Duma, don't do anything and earn half a million are considered far more useful ... And what about the pensioners? They have worked all their lives for the good of the country, since soviet times! And they still have to work in order to survive, instead of travelling and enjoying life, like foreign pensioners It's a shame!... And the regions, all these little towns where people live without jobs and money. Why did all factories close?"

These quotations illustrate the liberation of people's social imagination, or the opening of spatial and social horizons. People imagine a group larger than one's family or one's personal space as a point of reference, "we" who is seen as sharing the same life experience. For all these people, social inequality is the country's main problem, the main division, far more important in all accounts than national, ethnic, gender or generational ones. They advocate for the workers, those who produce, for the ex-workers (pensioners), for the working-poor in the regions who face social breakdown. In that sense, the group they relate to in their imagination while talking is not restricted to those people close to them. The group is imagined within the entire national borders. The group is an imagined community (Anderson, 2006) based on a sense of common life experience or common positions.

What made possible the awakening of such a vision of society? One condition is the process of inhabiting, analyzed in the first section, which implies a pragmatic anchorage in one's daily life, connectedness and the rebuilding of habitus or sense of one's place. Another favorable condition, I would argue, is the dominant populist and patriotic discourse, which has been developing since the second half of the 2000 s and the background it provides for acknowledging and naming new social divisions.

Such activity requires discursive resources that are not easily appropriated by those submerged in the hegemonic discourse. In the logic of Ernesto Laclau (2005), one condition for a new discourse to appear is the emergence of empty signifiers and names that are open to contradictory understandings. One such signifier gaining strength in Russia today is the category of "the people." Empty of specific signification, "the people" also opens the way for different understandings of who "the people" are. It could generate a sense of collective belonging and solidarity among the subordinates ("the simple people" in our cases). Therefore, it could serve as a ground and channel for the constitution of another, popular, populism.

A new populist and patriotic discourse has been developed by the Kremlin as a reaction to the massive 2005 protests against the social welfare reform called monetizatsia lgoty (monetization of social in-kind benefits), accentuated by the reaction to the 20112012 "For Fair Elections" movement and the annexation of Crimea in 2014. The Putin administration promotes a discourse of government concern for the people and a rejection of the neoliberal reforms of the 199os. Putin uses populist rhetoric and turns back to the "hard-working" and "conscientious" "ordinary folk," acknowledging the demand for a socially progressive state. He primarily speaks to 'ordinary citizens' and 'people who work' 
and "love Russia." ${ }^{5}$ His popularity is largely rooted in the fact that he has permitted many people from the bottom of the social hierarchy to recover a degree of recognition and self-esteem. The rhetoric of the liberal opposition only reproduces the populist discourse by inverting it (see also on this Yudin, 2017). The Moscow liberal intelligentsia holds a strongly anti-populist rhetoric, supporting the myth of the enlightened minority and the unenlightened majority, depicting "the mass post-Soviet people," especially lower class people from the regions, as 'paternalistically minded,' authoritarian, cynical, and materialistic (Gudkov, 2013; Gudkov, Dubin, Zorkaya, 2008). Derogatory terms which are used to refer to the unenlightened majority are very crude, such as sovki [people still "stuck" in the Soviet past] or vatniki [literally, "quilted jackets"] and are picked up by the power elite with inverse connotations. As a result, it is not rare in interviews to hear people emotionally asserting that they are not vatniki, but worthy citizens.

The Kremlin discourse and the anti-Kremlin discourse both provide new social markers and a renewed vision of society, which breaks with the "shock therapy" vision of the chaos, or the neoliberal vision of an individualistic society of consumers, competitors and risk-takers. The discourse conveys a new terminology and (old) new macro-sociological categories, such as "the working-class people", "ordinary Russian people", "simple people" that are appropriated by many people in their ordinary conversations. My fieldworks show, however, that there is a gap between the meanings given to these categories by the ruling and oppositional elites, and the meaning attributed by the people who identify themselves with these categories. One of the most striking mismatches is the presence or absence of social-economic inequality. The problem is silenced by the media from both ideological sides; it is hardly mentioned by intellectuals. On the contrary, in-depth interviews reveal a high proportion of people, particularly from lower classes, addressing the choking rise of social inequality.

Another aspect of the dominant discourse allows for different and ambivalent interpretations: the nationalistic rhetoric which has strengthened particularly after the annexation of the Crimea. Whatever people may think about any particular concrete feature of living in Russia (and critical views largely dominate), most of the interviewees support the project of rebuilding the "great Russia" and giving people reasons for being proud of their homeland. Instead of the national shame of the 199os, which is painfully remembered in many interviews, people now demonstrate a striking capacity to grasp the whole country, at least in their imagination. The restoration of the national frame (whatever its specific content, which I will not discuss here) and the strengthening of the nationalist discourse widens the geographical, territorial and social boundaries of the imagination. Interviews are full of mentions of "poor regions", "outrageously rich Moscow" or the "decaying countryside". Many interviewees embrace the whole of Russia when trying to assess the current situation in the country, comparing different regions or cities or places. Many refer to people "like us" living in other parts of Russia. This does not mean that the dominant identification is with the nation as the community of Russians.

5. From Putin's speech at the rally held on February 23, 2012, at Luzhniki in Moscow against the "For Fair Elections" movement. 
More often than the "we-Russians", the broader social-territorial category mentioned in interviews as "ours" is the social-economic "we" of the poor, despised and dominated but worthy people. As a whole, the interviews testify to an opening of the horizons of thinking, which obviously provide grounds for the development of macro-sociological groups of belonging.

It can be argued that we are witnessing a process of group making that has perhaps not led to stable collective identities, boundaries and institutions. However, something is unfolding which is worth trying to grasp for a better understanding of Russian society, as well as for theoretical elaboration. The study of collective identities (Brubaker, Cooper, 2000; Tilly, 2003, Melucci, 1996) and boundaries (Lamont, Molnar, 2002) is well developed, scholars in various fields try to grasp the process of group making in our post-modern pluralistic and fluid societies. The dominant feature of these studies is their constructivist stance. Most scholars avoid giving any essentialist features or objective existence to groups and stress the role of representations, imaginary, emotions and cognitive efforts involved in the construction of groups, especially on the part of the elites (although not reduced to it). These are useful insights to cover the wide range of practices and meaning making involved in the process. Post-soviet Russia, certainly along with other countries or cases, points to the importance of the materialistic and structural components in the process. As already highlighted, the process of imagining a reference group with which a person feels commonality requires first the foundation of "habitus", a corporal and physical inhabiting of and rootedness in one's quotidian and mundane world. The recovery of habitus is not achieved by the operation of the will or through cognitive work, but through the stabilization of life experience, regular interactions and practices of "inhabiting". Thanks to this physical and emotional reconciliation with one's immediate world, it becomes possible to take a stance on the larger world, to see it in a more or less meaningful way.

In an extremely unequal society, such as contemporary Russia, most lower class people see society through the lenses of socio-economic inequality. This view of the world has also emerged thanks to the (anti-)populist and (anti-)nationalist discourse of the ruling and intellectual elites which puts under the spotlight a new vocabulary to grasp reality, where the categories of "the people" and "the homeland" are at the fore. However, it would be oversimplifying to subsume the complex process of group making to this aspect. The extent to which the meanings of "the people" and "the homeland" used by the elites and lower class people coincide is under question. The elites have far more resources, symbolical power, first of all, to impose their view on the world. However, paradoxically enough, the principles of classification and the names that are imposed from above correspond to lower class people's social markers. Objectively then, both the elites and the lower class people benefited from the provisory outcome of the classification struggle.

The question remains of the mismatch in interpretations, which empirical qualitative studies concerning slight differences and nuances may clarify. A general theory is also needed, which would reconcile structural social inequality and spaces to maneuver for the struggle of classification and interpretation. An appropriate theory may be Bourdieu's 
theory of the social space and symbolic power, in which, along with objective social positions, classification and symbolical struggles play an important role in the structuration of the social order and the production of any class (Bourdieu, 1989). Symbolic boundaries are lines of social differentiation that appear to be obvious, taken-for-granted, and, thus, legitimate. I assume that, for now in Russia, social boundaries ("objectified forms of social differences manifested in unequal access to and unequal distribution of resources", in Lamont, Molnar, 2002: 168) and symbolic boundaries do not completely coincide, which prevents the solidification (common sense understanding) of social boundaries. The struggle over meanings and interpretations is still unfolding alongside the issue of social inequality (to raise or not the question in public debates). More likely to address the question of social inequality are those who experience its real oppressive manifestations in everyday life, while inhabiting their mundane close world and getting their vision of the wider world from their rootedness in their quotidian life experience. Therefore, there is a chance for those socially and symbolically dominated to influence the understanding of these "empty signifiers" (in today Russia, "the people" and "the nation") conceptualized by Ernesto Laclau (2005). These signifiers are open to debate over their contradictory meanings, and to the imposition of a class-based vision and division of society, where class means socio-economic class and not mere sociological layer (lower, middle, upper classes).

Certainly, lower class people have far less resources to influence the group making process than the economic, intellectual or political dominants. Their symbolical power is dependent on their strong anchorage in their daily life experience and the sense of commonality and solidarity which may develop along with their awareness of the growing socio-economic inequality. Against this tendency towards the forming of the lower class group are two strong constraints and obstacles. First, there is a strong discourse against any vision of a divided society, along whatever socio-economic divisions. The divisions which resonate in the political or intellectual debates are national divisions (the Russians as an undifferentiated whole and the rest of the world, particularly the West) and the people versus the power division. Sometimes some moral divisions arise, "good" people against "bad" people being the dominant line. These are not social divisions at all. The question of social inequality is almost never raised publically, at least not as a structuring principle of society. Part of the problem is also that lower class people do not have any spokesperson or organization, which Bourdieu presents as conditions for successful group making, especially concerning the symbolically dominated classes (Bourdieu, 1985). Thus, the commonality and connectedness which are developing now among lower class people, and their growing sense of social inequality, remain in the domain of the mundane. In a country where there is traditionally a strong symbolical distinction between the low-level and low prestige byt (mundane and everyday life) and the high-level and high prestige bytie (intellectual and spiritual life) (Boym, 1994), the former has little chance to win the battle over principles of vision and division of society. On the other hand, since lower class people in Russia are not a marginal few, but the absolute majority, 
the instruments they produce to understand the world may have some practical importance and consequences on the social order.

In the end, more as a strong hypothesis than as a conclusion, I would qualify the social world corresponding to the practical sense of the lower class people as a classbased perception of social inequality relying on an unexpressed, and maybe unconscious, Marxist frame for grasping the surrounding social reality. I am encouraged to make such an assertion by recent ethnographic studies which also stress "vernacular Marxism" as a strong framework for the understanding of Russian everyday worlds (Kruglova, 2017). As incredible as it may seem, I did not plan to finish the paper with Marxism, nor to come back to Pierre Bourdieu, one of my earliest favorite social theorists. The dynamics of a comprehensive analysis of the empirical data led me to Marx and Bourdieu. It is, as such, an interesting unplanned development of my thinking to reflect on.

\section{Conclusion}

What general conclusions can we draw from the above analysis to shed light on the way social ties and social imagination can develop among lower class people, who have been subjected to harsh social and economic destabilization?

First, a process of inhabiting one's social and material environment has to enfold, along with the recovering of habitus or a sense of occupying a "normal" place in society, and regular interactions with people recognized as occupying a similar place. This implies a certain degree of stabilization of social and economic structures, and more importantly, a sense of growing stability (the emergence of a social "order").

Second, rootedness in an inhabiting environment and in one's everyday experience gives lower class people the capacity to grasp the broader social space, to order what seemed to be messy and disordered, to draw some lines of differentiation and division. This occurs despite the dominant vision of the society as undivided, being one nation or one people, bad or good according to the elites' ideological preferences. This means that society is being restructured, represented as divided and unequal by those dominated, when they succeed in plenty trusting their everyday life experiences, against the erosion and invisibilization of social cleavages and the inequality driven by neo-liberal globalization and the dominant discourse.

In this classification struggle, nationalist and populist components of the dominant discourse can help those dominated to describe their intuitive knowledge of social reality and to recognize themselves to a certain extent using some words, such as "the people" or "the nation". However, what is at stake in this struggle is which meaning of these terms will become common sense. For now, the outcome of that struggle remains unclear.

To grasp the process, there is certainly a need to come back to the kind of traditional sociology which reconciles the constraining power of social structures (even, and maybe especially, when they seem confusing and ungraspable) and the structuring power of people sharing some common positions or places in the social world. That is why classics of social thoughts such as Marx or Bourdieu still have good days ahead. It may even 
be that a certain popular, vernacular or common sense version of Marxism still has an impact on the everyday experience for many lower class people.

\section{References}

Alexander J. C., Eyerman R., Gieson B., Smelser N. J., Sztompka P. (2004) Cultural Trauma and Collective Identity, Berkeley: University of California Press.

Anderson B. (2006) Imagined Communities: Reflections on the Origin and Spread of Nationalism, London: Verso.

Ashwin S. (1998) Endless Patience: Explaining Soviet and Post-Soviet Social Stability. Communist and Post-Communist Studies, vol. 31, pp. 187-198.

Bauman Z. (2000) Liquid Modernity, Cambridge: Polity.

Bauman Z. (2001) Identity in the Globalising World. Social Anthropology, vol. 9, no 2, pp. 121-129.

Beck U. (1992) Risk Society: Towards a New Modernity, London: SAGE.

Boltanski L., Chiapello E. (1999) Le nouvel esprit du capitalisme, Paris: Gallimard.

Bourdieu P. (1985) The Social Space and the Genesis of Groups. Theory and Society, vol. 14, no 6, pp. 723-744.

Bourdieu P. (1989) Social Space and Symbolic Power. Sociological Theory, vol. 7, no 1, pp. 14-25.

Bourdieu P. (1990) The Logic of Practice, Cambridge: Polity.

Bourdieu P. (1999) The Weight of the World: Social Suffering in Contemporary Society, Cambridge: Polity.

Bourdieu P. (2004) Science of Science and Reflexivity, Cambridge: Polity.

Boym S. (1994) Common Places: Mythologies of Everyday Life in Russia, Harvard: Harvard University Press.

Breman J., van der Linden M. (2014) Informalizing the Economy: The Return of the Social Question at a Global Level. Development and Change, vol. 45, pp. 920-940.

Brubaker R., Cooper F. (200o) Beyond "Identity". Theory and Society, vol. 29, no 1, pp. 1-47.

Clément K. (1999) Les ouvriers russes dans la tourmente du marché, Paris: Syllepse.

Clément K. (ed.) (2013) Gorodskie dvizhenija Rossii v 20o9-2012 godah: na puti k politicheskomu [Urban Movements in Russia, 2009-2012: On the Road Towards Politics], Moscow: New Literary Observer.

Clément K. (2015) Unlikely Mobilisations: How Ordinary Russian People Become Involved in Collective Action. European Journal of Cultural and Political Sociology, vol. 2, no 3-4, pp. 211-240.

Collins R. (2014) Interaction Ritual Chains, Princeton: Princeton University Press.

Crossley N. (2001) The Phenomenological Habitus and Its Construction. Theory and Society, vol. 30, no 1, pp. 81-120.

Durkheim E. (2008 [1912]) The Elementary Forms of the Religious Life, Mineola: Dover. 
Giddens A. (1991) Modernity and Post-Modernity: Self and Society in the Late Modern Age, Cambridge: Polity.

Goffman E. (1974) Frame Analysis: An Essay on the Organization of Experience, Harvard: Harvard University Press.

Gudkov L. (2013) Russian Cynicism: Symptom of a Stagnant Society. Open Democracy, 22 October 2013. Available at: https://www.opendemocracy.net/od-russia/lev-gudkov/ russian-cynicism-symptom-of-stagnant-society (accessed 20 November 2017).

Gudkov L., Dubin B., Zorkaya N. (2008) Postsovetskij chelovek i grazhdanskoe obshhestvo [Post-Soviet Man and Civil Society], Moscow: MSPS.

Kruglova A. (2017) Social Theory and Everyday Marxists: Russian Perspectives on Epistemology and Ethics. Comparative Studies in Society and History, vol. 59, no 4, pp. 759785.

Laclau E. (2005) On Populist Reason, London: Verso.

Lamont M., Molnár V. (2002) The Study of Boundaries in the Social Sciences. Annual Review of Sociology, vol. 28, pp. 167-195.

Melucci A. (1989) Nomads of the Present: Social Movements and Individual Needs in Contemporary Society, Philadelphia: Temple University Press.

Melucci A. (1996) Challenging Codes: Collective Action in the Information Age, Cambridge: Cambridge University Press.

Morris J. (2016) Everyday Post-Socialism: Working-Class Communities in the Russian Margins, New York: Palgrave Macmillan.

Ries N. (1997) Russian Talk: Culture and Conversation during Perestroika, Ithaca: Cornell University Press.

Sennet R. (1998) The Corrosion of Character: The Personal Consequences of Work in the New Capitalism, New York: W. W. Norton.

Standing G. (2011) The Precariat: The New Dangerous Class, London: Bloomsbury Academic.

Stompka P. (200o) Cultural Trauma: The Other Face of Social Change. European Journal of Social Theory, vol. 3, no 4, pp. 449-466.

Tilly Ch. (2003) Political Identities in Changing Polities. Social Research, vol. 70, no 2, pp. 605-619.

Yudin G. (2017) “Scratch a Russian Liberal and You'll Find an Educated Conservative”: An Interview with Russian Sociologist Greg Yudin. LeftEast, 23 March 2017. Available at: http://www.criticatac.ro/lefteast/scratch-a-russian-liberal-and-youll-find-aneducated-conservative-an-interview-with-sociologist-greg-yudin/ (accessed 20 November 2017).

Wacquant L. (2002) Scrutinizing the Street: Poverty, Morality, and the Pitfalls of Urban Ethnography. American Journal of Sociology, vol. 107, no 6, pp. 1468-1532.

Wacquant L. (2014) Putting Habitus in Its Place: Rejoinder to the Symposium. Body \& Society, vol. 20, no 2, pp. 118-139. 


\section{Социальное воображение и солидарность в прекарное время: случай трудящихся классов в постсоветской России}

\section{Карин Клеман}

PhD социологии, доцент Факультета свободных искусств и наук Санкт-Петербургского государственного университета, директор Центра им. Эндрю Гагарина по изучению гражданского общества и прав человека

Адрес: Университетская набережная, д. 7-9, Санкт-Петербург, Российская Федерация 199034 E-mail: carine_clement@hotmail.com

Статья стремится обогатить библиографию работ о процессе формирования социальных групп, взяв в качестве объекта исследования людей из трудящихся классов в постсоветской России. Автор предлагает некоторые выводы относительно того, как в глобальном неолиберальном капитализме могут быть преодолены прекаризация и атомизация. На основании обширной базы данных, состоявшей из глубинных интервью, взятых в разных регионах, и нескольких наблюдений, сделанных автором, исследуется, как устанавливаются социальные связи и какова роль социального воображения у представителей трудящихся классов, подвергшихся серьезной социальной и экономической дестабилизации. Во-первых, должен иметь место процесс «обживания» собственного социального и материального окружения, одновременный с восстановлением «габитуса» или чувством, что человек занимает «нормальное» место в обществе. Также должны восстановиться регулярные взаимодействия с людьми, признаваемыми в качестве «обитателей схожих мест». Во-вторых, опора на собственный повседневный опыт дает людям из трудящихся классов способность действовать в широком социальном пространстве и выстраивать собственные линии дифференциации и отделения, в то время как популистский и антипопулистский дискурсы предоставляют рамку для признания и обозначения новых социальных разграничений. Для того чтобы понять эти процессы, считает автор, было бы полезно вернуться к идеям классиков критической (или структурально-конструктивисткой) социологии - Марксу или Бурдье.

Ключевые слова: социальное воображение, обитание, повседневный опыт, трудящиеся классы, социальные разделения, постсоветская Россия, прекарность 